\title{
UNSUR UNSUR NEGARA
}

\author{
Nama : Leni Putri \\ Email: leniputri7484@gmail.com \\ No BP: 2010003600094 \\ Universitas Ekasakti-AAI Padang. \\ Fakultas Hukum
}

\section{A. PENDAHULUAN}

Alhamdulliah segala puji syukur penulis ucapkan kehadirat Allah SWT yang telah memberikan Rahmat dan Karunianya kepada kita semua terutama kepada penulis dan shalawat beriring salam disampaikan kepada nabi besar kita yakni Nabi Muhammad SAW, sehingga penulis dapat menyelesaikan penulisan makalah Ilmu Negara yang berjudul " Unsur - Unsur Negara " sebagai salah satu syarat memenuhi mata kuliah di Universitas Ekasakti Padang.

Sebagai sebuah organisasi, negara memiliki unsur - unsur yang tidak dimiliki oleh organisasi apapun yang ada didalam masyarakat. Secara umum, unsur negara ada yang bersifat konstitutif dan ada pula yang bersifat deklaratif. Unsur konstitutif maksudnya unsur yang mutlak atau harus ada didalam suatu negara. Sedangkan unsur deklaratif hanya menerangkan adanya negara.

Adapun unsur - unsur negara yang bersifat konstitutif adalah harus ada rakyat, wilayah tertentu, dan pemerintahan yang berdaulat. Ketiga unsur tersebut bersifat konstitutif karena merupakan syarat mutlak bagi terbentuknya negara. Apabila saah satu unsur tersebut tidak ada atau tidak lengkap, maka tidak bisa disebut sebagai negara. 
Disamping itu, terdapat pula unsur deklaratif, yakni harus ada pengakuan dari negara lain. Unsur deklaratif ini sangatlah penting karena pengakuan dari negara lain.

\section{Tujuan Makalah}

Tujuan salah satu penulis membuat makalah adalah :

a. Sebagai salah satu syarat untuk memenuhi nilai

b. Untuk memperluas wawasan penulis

c. Agar dapat untuk mengembangkan wawasan kepada orang banyak

2. Rumusan Masalah

a. Apa saja yg termasuk kedalam unsur unsur-unsur negara?

b. Pengertian dari rakyat, wilayah, dan pemerintah?

c. Fungsi dari rakyat, wilayah dan pemerintah?

\section{B. PEMBAHASAN}

Unsur untuk melengkapi arti negara perlu kiranya diuraikan unsur - unsur negara ada bagiannya untuk menjadi negara itu ada. Unsur - unsur negara dikenal dalam tiga hal yaitu :

1. Rakyat

Rakyat adalah semua orang yang menjadi penghuni suatu negara. Tanpa rakyat mustahil negara akan terbentuk. Leacock mengatakan bahwa, " Negara tidak akan berdiri tanpa adanya sekelompok orang yang mendiami bumi ini" . Banyak yang menimbulkan pertanyaan dari sebuah penjelasan tersebut. Berapa banyak jumlah penduduk untuk membuat suatu negara?. Plato menjelaskan suatu wilayah membutuhkan 5040 penduduk atau orang.

Rakyat terdiri dari penduduk dan bukan penduduk. Penduduk ialah semua orang yang ingin menetap disebuah wilayah atau negara tertentu. Mereka yang ada dalam wilayah yang 
bertujuan tidak ingin menetap, tidak dapat disebut penduduk. Misalnya orang yang ingin berkunjung karena wisata. Dan ada juga beberapa istilah yang erat dengan pengertian rakyat yaitu :

a) Rumpun (ras)

Rumpun diartikan sebagai sekumpulan manusia yang merupakansuatu kesatuan karena mempunyai ciri - ciri jasmani yang sama, seperti warna kulit warna rambut, dan lainnya. Karena persamaannya ciri - ciri jasmani itu maka penduduk dunia dibagi dalam macam - macam rumpun, seperti rumpun melayu, rumpung kuning, rumpun putih, dan sebagainya.

b) Bangsa ( volks)

Bangsa diartikan sebagai kumpulan manusia yang merupakan satu kesatuan karena mempunyai perasaan kebudayaan. Misalnya : bahasa adat kebiasaan, agama dan sebagainya.

c) Nazi ( natie)

Natie juga sering disebut sebagai bangsa akan tetapi mempunyai ciri-ciri yang berbeda. Natie diartikan sebagai sekumpulan manusia yang merupakan suatu kesatuan karena mempunyai kesatuan politik yang sama. Ciri jasmaniah maupun kebudayaan bukan syarat mutlak bagi terbentuknya suatu bangsa (natie). Oleh karena itu disebut sebagai nasional oleh karena, negara didirikan atas keadaan nasional. Maka rakyat mempunyai arti yang netral dan rakyat sebagai salah satu unsur dari pada negara harus dihubungkan dengan ikatannya dengan negara, oleh karena itu rakyat harus dimaksudkan sebagai warga negara. Ikatan warga negara tersebut menimbulkan hak dan kewajiban 
baginya. Dari hak dan kewajiban tersebut maka warga negara dapat disimpulkan dalam empat hal:

\section{Status Positif}

Status positif seorang warga ialah memberi hak kepadanya untuk menuntut tindakan positif daripada negara mengenai perlindungan atas jiwa, raga, milik, kemerdekaan dan lain sebagainya.

\section{Status Negatif}

Starus negatif seorang warga negara akan memberi jaminan kepadanya bahwa negara tidak boleh campur tangan terhadap hak-hak asasi warga negaranya. Namun dalam keadaan tertentu negara dapat melanggar hak-hak tersebut jika tindakannya untuk kepentingan umum.

\section{Status Aktif}

Status aktif ini memberi hak kepada setiap warga negaranya untuk ikut serta dalam pemerintahan. Untuk mewujudkan hak ini setiap warga negaranya diberi hak untuk memilih dan dipilih sebagai anggota dalam Dewan Perwakilan Rakyat.

\section{Status Passif}

Status passif ini merupakan kewajiban bagi setiap warga negara untuk mentaati dan tunduk kepada seluruh perintah warga negaranya.

2. Wilayah

Wilayah tertentu ialah batas wilayah dimana kekuasaan negara itu tidak berlaku diluar batas wilayahnya karena bisa menimbulkan sengketa internasional, walaupun sebagai pengecualian 
dikenal apa yang disebut daerah eksteritorial yang artinya kekuasaan negara bisa berlaku diluar daerah kekuasaannya sebagai pengecualian misalnya ditempat kediaman kedutaan asing berlaku kekuasaan negara asing itu. Mengenai batas wilayah negara itu orang tidak dapat melihat dalam Undang-Undang Dasar Negara, tapi merupakan pernjanjian (traktat) antara dua negara atau lebih yang berkepentingan dan biasanya merupakan negara tetangga. Jika hanya antara dua negara maka perjanjian tersebut bersifat billateral. Jika lebih maka sifat perjanjian tersebut multilateral. Wilayah/teritori mempunyai arti luas yang meliputi: Udara, Darat dan Laut. Ketiganya ditentukan oleh perjanjian internasional.

Karaktersitik wilayah bisa berupa kondisi alam, ekonomi, demografi, dan sosial-budaya. Beberapa contoh wilayah yang ada di permukaan bumi antara lain:

$>$ Wilayah hutan hujan tropis (region alamiah)

Amerika latin (region budaya)

Kepulauan Wallacea (region fauna)

$>$ Corn belt (region pertanian)

Zona dataran rendah Jakarta (region fisiografi)

Secara umum suatu wilayah terbagi menjadi dua, yaitu:

1. Wilayah formal

Wilayah ini identik dengan definisi wilayah secara umum, yaitu suatu daerah atau kawasan di muka bumi yang memiliki karakteristik yang khas sehingga dapat dibedakan dari wilayah lain di sekitarnya.

2. Wilayah fungsional

Suatu kawasan yang terdiri atas beberapa pusat wilayah yang berbeda fungsinya. 
Contoh jelas dari wilayah fungsional adalah perkotaan. Dilihat dari konsepnya, wilayah perkotaan terdiri atas tiga komponen, yaitu:

1) Nodus atau inti, yang merupakan pusat kota.

2) Internal area (hinterland), wilayah sekitar kota yang fungsinya memasok kebutuhan harian kota tersebut.

3) area, merupakan jalur penghubung antara kota wilayah pemasok kebutuhan kota tersebut.

\section{Pemerintah}

a. Pengertian Pemerintah

Pemerintah merupakan alat bagi negara dalam menyelenggarakan segala kepentingan warganya dan merupakan alat dan juga dalam mewujudkan tujuan yang sudah ditetapkan. Pemerintah harus diartikan luas yang mencakup semua badan-badan negara. Yang penting adalah pemerintah yang berkuasa harus diakui oleh rakyatnya karena pada hakekatnya pemerintah merupakan pembawa suara dari rakyat sehingga pemerintah dapat berdiri stabil. Demikian pula pengakuan dari luar ata negara lain.

Pemerintah adalah sekelompok orang atau organisasi yang diberikan kekuasaan untuk memerintah serta memiliki kewenangan dalam membuat dan menerapkan hukum di suatu wilayah. Pemerintah merupakan lembaga atau badan publik yang bertugas mewujudkan tujuan negara. Lembaga itu juga diberikan kewenangan untuk melaksanakan kepemimpinan dan koordinasi pemerintahan serta pembangunan masyarakat dari berbagai lembaga dimana mereke ditempatkan.

b. Fungsi ada empat fungsi pemerintah yakni: 
* Pelayanan, meliputi pelayanan publik dan pelayanan sipil yang mengedepankan kesetaraan. Pelayanan yang dilakukan pemerintah pusat mencakup masalah luar negeri, peradilan, keuangan, agama, pertahanan dan keamanan.

* Pengaturan, yakni membuat peraturan perundang-undangan yang mengatur hubungan manusia di dalam masyarakat agar kehidupan berjalan lebih harmonis dan dinamis.

* Pembangunan, yakni pemerintah sebagai pemacu pembangunan, baik di baik itu infrastruktur maupun pembangunan SDM di wilayahnya.

* Pemberdayaan, yakni pemerintah berperan mendukung otonomi daerah sehingga masingmasing daerah dapat mengelola sumber daya secara maksimal.

\section{c. Tujuan Pemerintahan}

Suatu pemerintahan dibentuk pasti dengan beberapa tujuan. Yang pasti pemerintah harus bertujuan meningkatkan kesejahteraan rakyatnya. Adapun beberapa tujuan pemerintahan adalah sebagai berikut:

1) hak asasi manusia, kebebasan, kesetaraan, perdamaian, dan keadilan bagi seluruh rakyatnya.

2) konstitusi sehingga setiap warga negara diperlakukan dengan adil.

3) Perdamaian dan keamanan di dalam masyarakat dengan menerapkan hukum secara adil.

4) Melindungi kedaulatan bangsa dari berbagai unsur yang mengancam, baik dari dalam maupun dari luar.

5) Membuat dan menjaga sistem moneter sehingga memungkinkan perdagangan domestik dan internasional berjalan dengan baik. 
6) Menarik pajak dan menetapkan APBN secara bijak sehingga pengeluaran negara tepat sasaran.

7) Membuka dan menciptakan lapangan pekerjaan sebanyak-banyaknya sehingga kesejahteraan masyarakat menjadi lebih baik.

8) Menjaga hubungan diplomatik dengan negara lain dengan cara membangun kerjasama di berbagai bidang.

d. Jenis pemerintahan Ada banyak jenis pemerintahan yang berlaku atau pernah berlaku di dunia. Saat ini banyak negara memberlakukan pemerintahan demokrasi seperti contohnya Indonesia Selain demokrasi ada banyak lagi jenis pemerintahan loh. Ini daftarnya.

1) Monarki

2) Tirani

3) Aristokasi

4) Oligarki

5) Demokrasi

6) Teknokrasi

7) Timokrasi

8) Kleptokrasi

9) Oklokrasi

10) Plutokrasi

\section{PENUTUP}

1. Kesimpulan 
Negara adalah suatu wilayah di permukaan bumi yang kekuasaannya baik politik, militer, ekonomi, sosial maupun budayanya diatur oleh pemerintahan yang berada di wilayah tersebut. Unsur- unsur pembentuk Negara terdiri atas Rakyat, Wilayah.Pemerintah yang berdaulat dan pengakuan dari Negara lainBangsa adalah sekelompok manusia / orang yang memiliki cita-cita bersama yang mengikat dan menjadi satu kesatuan, perasaan senasib sepenanggungan, karakter yang sama, adat istiadat / budaya yang sama, satu kesatan wilayah, teroganisir dalam satu wilayah hukum. Istilah Negara merupakan terjemahan dari de staat (belanda), the state (inggris), I'etat (prancis), statum (latin), lo stato (Italia), dan der staat (jerman).Menurut bahasa sansekerta, nagari atau Negara, berarti kota, sedangkan menurut bahasa suku-suku diIndonesia sering disebut negeri atau Negara, yaitu tempat tinggal.Secara umum dikenal adanya 2 proses pembentukan bangsa-negara, yaitu model ortodoks dan model mutakhir. Unsur-unsur negara antara lain rakyat atau masyarakat, wilayah / daerah, meliputi udara, darat, dan perairan (perairan bukan merupakan syarat mutlak) dan pemerintah yang berdaulat.Beberapa teori terjadinya negara adalah Teori hukum alam, Teori ketuhanan dan Teori perjanjian

\section{Saran}

Menyadari bahwa penulis masih jauh dari kata sempurna, kedepannya penulis akan lebih fokus dan details dalam menjelaskan tentang makalah di atas dengan sumber - sumber yang lebih banyak yang tentunya dapat di pertanggung jawabkan. Untuk saran bisa berisi kritik atau saran terhadap penulisan juga bisa untuk menanggapi. Penyelesaian makalah ini memerlukan berbagai data, informasi serta pengarahan - pengarahan. Maka pada kesempatan ini, penulis menyampaikan terimakasih atas segala bantuan yang telah diberikan. 


\section{DAFTAR PUSTAKA}

Darmini Roza dan Laurensius Arliman S Peran Pemerintah Daerah Di Dalam Melindungi Hak Anak Di Indonesia, Masalah-Masalah Hukum, Volume 47, Nomor 1, 2018.

Laurensius Arliman S, Komnas HAM dan Perlindungan Anak Pelaku Tindak Pidana, Deepublish, Yogyakarta, 2015.

Laurensius Arliman S, Penguatan Perlindungan Anak Dari Tindakan Human Trafficking Di Daerah Perbatasan Indonesia, Jurnal Selat, Volume 4, Nomor 1, 2016.

Laurensius Arliman S, Problematika Dan Solusi Pemenuhan Perlindungan Hak Anak Sebagai Tersangka Tindak Pidana Di Satlantas Polresta Pariaman, Justicia Islamica, Volume 13, Nomor 2, 2016.

Laurensius Arliman S, Pelaksanaan Perlindungan Anak Yang Tereksploitasi Secara Ekonomi Oleh Pemerintah Kota Padang, Veritas et Justitia, Volume 2, Nomor 1, 2016.

Laurensius Arliman S, Kedudukan Ketetapan MPR Dalam Hierarki Peraturan PerundangUndangan Di Indonesia, Lex Jurnalica, Volume 13, Nomor 3, 2016. 
Laurensius Arliman S, Komnas Perempuan Sebagai State Auxialiary Bodies Dalam Penegakan Ham Perempuan Indonesia, Justicia Islamica, Volume 14, Nomor 2, 2017.

Laurensius Arliman S, Peranan Pers Untuk Mewujudkan Perlindungan Anak Berkelanjutan Di Indonesia, Jurnal Ilmu Hukum Tambun Bungai, Volume 2, Nomor 2, 2017.

Laurensius Arliman S, Mewujudkan Penegakan Hukum Yang Baik Untuk Mewujudkan Indonesia Sebagai Negara Hukum, Jurnal Hukum Doctrinal, Volume 2, Nomor 2, 2017.

Laurensius Arliman S, Participation Non-Governmental Organization In Protecting Child Rights In The Area Of Social Conflict, The 1st Ushuluddin and Islamic Thought International Conference (Usicon), Volume 1, 2017.

Laurensius Arliman S, Partisipasi Masyarakat Dalam Pembentukan Perundang-Undangan Untuk Mewujudkan Negara Kesejahteraan Indonesia, Jurnal Politik Pemerintahan Dharma Praja, Volume 10, Nomor 1, 2017, https://doi.org/10.33701/jppdp.v10i1.379.

Laurensius Arliman S, Peran Komisi Perlindungan Anak Indonesia Untuk Mewujudkan Perlindungan Anak, Jurnal Respublica Volume 17, Nomor 2, 2018.

Laurensius Arliman S, Menjerat Pelaku Penyuruh Pengrusakan Barang Milik Orang Lain Dengan Mempertimbangkan Asas Fungsi Sosial, Jurnal Gagasan Hukum, Volume 1, Nomor 1, 2019. 
Laurensius Arliman S, Ilmu Perundang-Undangan Yang Baik Untuk Negara Indonesia, Deepublish, Yogyakarta, 2019.

Laurensius Arliman S, Isdal Veri, Gustiwarni, Elfitrayenti, Ade Sakurawati, Yasri, Pengaruh Karakteristik Individu, Perlindungan Hak Perempuan Terhadap Kualitas Pelayanan Komnas Perempuan Dengan Kompetensi Sumber Daya Manusia Sebagai Variabel Mediasi, Jurnal Menara Ekonomi: Penelitian dan Kajian Ilmiah Bidang Ekonomi, Volume 6, Nomor 2, 2020.

Laurensius Arliman S, Pendidikan Kewarganegaraan, Deepublish, Yogyakarta, 2020.

Laurensius Arliman S, Makna Keuangan Negara Dalam Pasal Pasal 23 E Undang-Undang Dasar 1945, Jurnal Lex Librum, Volume 6, Nomor 2 Juni 2020, http://dx.doi.org/10.46839/1ljih.v6i2.151.

Laurensius Arliman S, Kedudukan Lembaga Negara Independen Di Indonesia Untuk Mencapai Tujuan Negara Hukum, Kertha Semaya Journal Ilmu Hukum, Volume 8, Nomor 7, 2020.

Laurensius Arliman S, Pelaksanaan Assesment Oleh Polres Kepulauan Mentawai Sebagai Bentuk Pelaksanaan Rehabilitasi Bagi Pecandu Dan Korban Penyalahgunaan Narkotika, Jurnal Muhakkamah, Volume 5, Nomor 1, 2020. 
Laurensius Arliman S, Aswandi Aswandi, Firgi Nurdiansyah, Laxmy Defilah, Nova Sari Yudistia, Ni Putu Eka, Viona Putri, Zakia Zakia, Ernita Arief, Prinsip, Mekanisme Dan Bentuk Pelayanan Informasi Kepada Publik Oleh Direktorat Jenderal Pajak, Volume 17, No Nomor, 2020.

Larensius Arliman S, Koordinasi PT. Pegadaian (Persero) Dengan Direktorat Reserse Narkoba Polda Sumbar Dalam Penimbangan Barang Bukti Penyalahgunaan Narkotika, UIR Law Review, Volume 4, Nomor 2, 2020, https://doi.org/10.25299/uirlrev.2020.vol4(1).3779.

Laurensius Arliman S, Tantangan Pendidikan Kewarganegaraan Pada Revolusi 4.0, Ensiklopedia Sosial Review, Volume 2, Nomor 3, 2020.

Muhammad Afif dan Laurensius Arliman S, Protection Of Children's Rights Of The Islamic And Constitutional Law Perspective Of The Republic Of Indonesia, Proceeding: Internasional Conference On Humanity, Law And Sharia (Ichlash), Volume 1, Nomor 2, 2020.

Otong Rosadi danLaurensius Arliman S, Urgensi Pengaturan Badan Pembinaan Idelogi Pancasila Berdasarkan Undang-Undang Sebagai State Auxiliary Bodies yang Merawat Pancasila dalam Perspektif Hak Asasi Manusia, Prosiding Konferensi Nasional Hak Asasi Manusia, Kebudayaan dan Tujuan Pembangunan Berkelanjutan Indonesia pada Masa Pandemi Covid-19: Tantangan untuk Keilmuan Hukum dan Sosial Volume 1, Universitas Pancasila, Jakarta, 2020. 